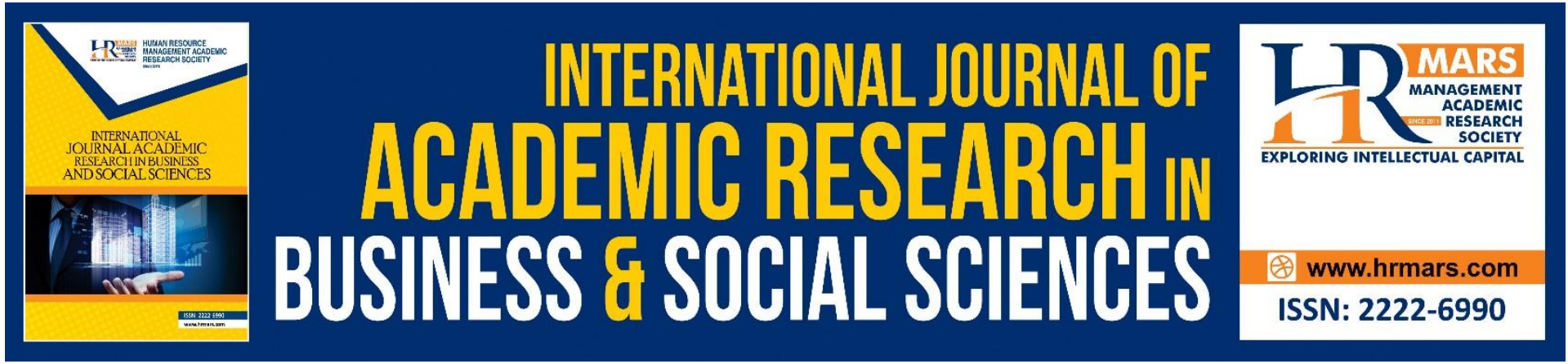

\title{
Language Learning Strategies in Acquiring English Language Skills among Year 5 Pupils in Rural Areas in Southern Malaysia
}

Tee Shu Min, Chen Xiu Wei, Nurzawanah Rohaizat, Kalsum Mohamed, Ang Fong Nie, Harwati Hashim

To Link this Article: http://dx.doi.org/10.6007/IJARBSS/v11-i7/10353 DOI:10.6007/IJARBSS/v11-i7/10353

Received: 09 May 2021, Revised: 13 June 2021, Accepted: 05 July 2021

Published Online: 30 July 2021

In-Text Citation: (Min et al., 2021)

To Cite this Article: Min, T. S., Wei, C. X., Rohaizat, N., Mohamed, K., Nie, A. F., \& Hashim, H. (2021). Language Learning Strategies in Acquiring English Language Skills among Year 5 Pupils in Rural Areas in Southern Malaysia. International Journal of Academic Research in Business and Social Sciences, 11(7), 1247-1256.

Copyright: (c) 2021 The Author(s)

Published by Human Resource Management Academic Research Society (www.hrmars.com)

This article is published under the Creative Commons Attribution (CC BY 4.0) license. Anyone may reproduce, distribute, translate and create derivative works of this article (for both commercial and non-commercial purposes), subject to full attribution to the original publication and authors. The full terms of this license may be seen at: http://creativecommons.org/licences/by/4.0/legalcode

Vol. 11, No. 7, 2021, Pg. 1247 - 1256

http://hrmars.com/index.php/pages/detail/IJARBSS

JOURNAL HOMEPAGE

Full Terms \& Conditions of access and use can be found at http://hrmars.com/index.php/pages/detail/publication-ethics 


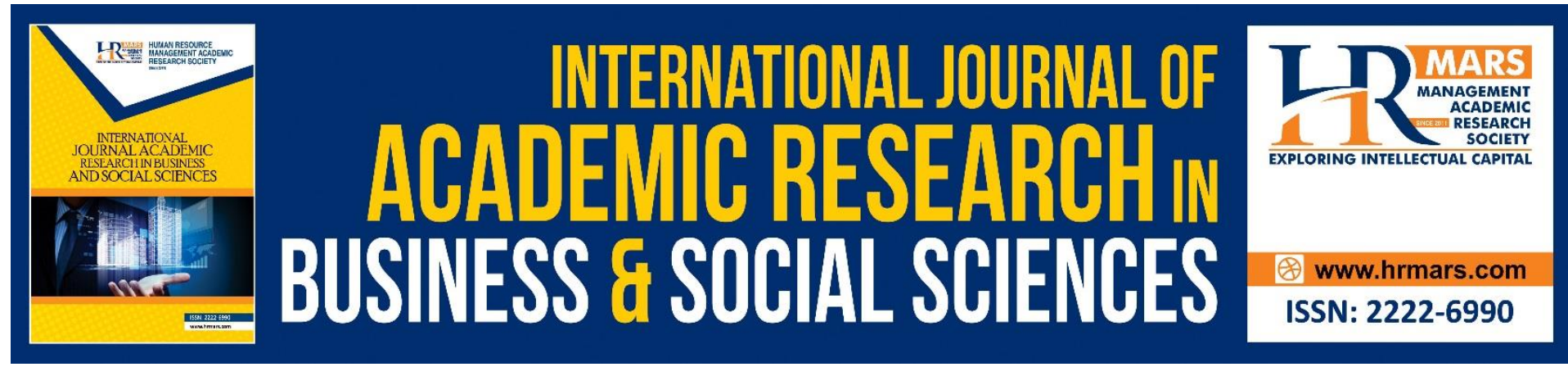

\title{
Language Learning Strategies in Acquiring English Language Skills among Year 5 Pupils in Rural Areas in Southern Malaysia
}

\author{
Tee Shu Min ${ }^{1,6}$, Chen Xiu Wei ${ }^{2,6}$, Nurzawanah Rohaizat ${ }^{3,6}$, \\ Kalsum Mohamed ${ }^{4,6}$, Ang Fong Nie ${ }^{5,6}$, Harwati Hashim ${ }^{6}$ \\ ${ }^{1}$ Sekolah Jenis Kebangsaan Cina Kahang, 86700 Kluang, Johor, Malaysia, ${ }^{2}$ Sekolah Jenis \\ Kebangsaan Cina Malayan, 86100 Ayer Hitam, Johor, Malaysia, ${ }^{3}$ Politeknik Sultan Abdul \\ Halim Mua'dzam Shah, 06000 Jitra, Kedah, Malaysia, 'Sekolah Kebangsaan Sungai Bunyi, \\ 82000 Pontian, Johor, Malaysia, ${ }^{5}$ Sekolah Jenis Kebangsaan Cina Chung Hwa, 89900 Tenom, \\ Sabah, Malaysia, ${ }^{6}$ Faculty of Education, Universiti Kebangsaan Malaysia, 43600 Bangi, \\ Malaysia
}

\begin{abstract}
Language Learning Strategies (LLS) and their advantages in enhancing and acquiring second language learning skills are not consciously known, especially to young learners. The main objective of this study is to identify the most preferred language learning strategies by the Year 5 primary pupils in rural areas in Southern Malaysia and the least practiced strategies in learning the English language. This study adopted a quantitative research design by adapting the Strategy Inventory for Language Learning questionnaire as a research instrument. The data was collected from 70 respondents by using a simple random sampling technique and then analysed descriptively. Through a comparison of means, this study had discovered that various strategies were practiced by the respondents. However, the most employed strategy is memory strategies, while the affective strategies are favoured the least. It is hoped that this study may give some insights and benefits to the ESL teachers in enhancing their teaching and learning process by introducing and emphasising various learning strategies for better selfregulated learning.
\end{abstract}

Keywords: ESL, Language Learning Strategies, Rural Primary Schools

\section{Introduction}

An Overview

Language Learning Strategies among language practitioners has been an interesting research topic, especially in finding out the strategies adopted by the successful learners in which are applicable for the less successful learners specifically in second language acquisition. Learning strategies can be classified into six groups: cognitive, metacognitive, memory-related, compensatory, affective, and social (Oxford, 2003). According to Scarcela and Oxford (1992) learning strategies can be defined as particular acts, behaviours, procedures, or techniques employed by the learners to enhance their own learning, such as seeking out discussion partners or encouraging oneself to face a tough language job. As for 
Chamot and Kupper (1989); O'Malley and Chamot (1990), they described language learning strategies as precise thoughts and activities that maximise the learning process and comprehension of new input and information. These methods become a valuable toolkit for active, aware, and purposeful self-regulation of learning when the learner actively picks techniques that fit his or her learning style and the second language task at hand. It is also crucial to recognise that individual students' learning styles and strategies can complement or clash with a specific educational methodology (Oxford, 2003). This has further been supported by Hashim et al (2018) that learners must be able to recognise their individual learning styles and preferences in order to determine which language learning strategies are best for them, so that the methods can become habits and eventually turn them into good language learners.

The first publication on English language learning strategies dates from 1996, when Mohamed Amin published a seminal doctoral dissertation that sparked considerable interest in the field of language learning in the years that followed (Saad et al., 2016). Furthermore, according to Macaro (2006), there has been a lot of interest in the learning processes that people use when learning and utilising second languages. Despite this long history, Saad et al (2012) believe that the body of literature in Malaysia on English teaching practices is still in its early stages. While English language is one of the most important subjects in the Malaysian education system, there are insufficient literatures regarding the language learning strategies employed by the primary pupils, specifically in the rural area.

In the last few decades, the field of language learning and instruction has seen significant changes. The focus on deploying various teaching approaches no longer provides language teachers with a solution. Despite their efforts, students' language learning, particularly in the setting of second languages, has not improved significantly. The focus has switched to the learners; learner autonomy is now the focus. Unfortunately, primary pupils from the rural areas are somehow overlooked at this matter.

\section{Research Objective}

The objective of this study is to explore the language learning strategies practiced by the Year 5 pupils in rural areas in Southern Malaysia in acquiring English language skills. This study too will identify the most and least preferred strategies which include memory strategies, cognitive strategies, compensation strategies, metacognitive strategies affective strategies and social strategies. Thus, this will serve as a guideline for the teachers in preparing more relevant materials and solutions in improving the pupils' English language learning in school depending on the personal capabilities. This research will be grounded on one main research question;

1. Which Language Learning Strategy is employed the most by the pupils in rural school to acquire the English language skills?

\section{Literature Review}

\section{The role of Language Learning Strategies (LLS) in Language Learning and Teaching}

The role of LLS has bring a major change in the teaching and learning process in Malaysia education which can be seen in the transformation that take place in Malaysia's education. One of the transformations is to use student centered approach in the teaching and learning process in which had an influence on the learning strategies used in classroom. One of the main roles of LLS is to help learners develop their own awareness of thinking processes such as meta cognitive and help learners to acquire effective ways to sustain the 
information that come from the learning environment. Acquiring and using good language learning strategies can help learners to improve their literacy skills as learners with poor performance in classroom can improve their learning performance by choosing and using the appropriate learning strategies (Chamot, 1998). Hence, the proper use of LLS help learners to learn and acquire new language. The correct choice of LLS helped to produce learners with great communicative competency (Lessard-Clouston, 1997). Communicative competency is one of the positive outcomes from the proper use of LLS. This indicates that learners who are competent in communication are the learners who are able to use LLS appropriately and apply the knowledge to other subject areas and become proficient in the target language. Therefore, it is important for educators to identify the appropriate language learning strategies which are suitable for their classroom.

However, there are obstacle in identifying and exploring the type of LLS use by learners. This is due to the fact that LLS usually can only be traced from the behaviours shown by language learners while in the process of teaching and learning (Griffiths, 2004). Therefore, studies have been conducted to identify the LLS use by learners through various form of data gathering method (Oxford, 1986). The instruments used in this study are one of the data gathering method used to investigate the LLS among learners.

\section{Methodology}

The study has employed a survey research design which is a quantitative research method used for collecting data from a set of respondents. In the study, the researchers have identified the issue to be studied, which is to explore the language learning strategies practiced by the Year 5 pupils in rural areas in Southern Malaysia in acquiring English language skills and to identify the most and least preferred strategies which include the memory strategies, cognitive strategies, compensation strategies, metacognitive strategies affective strategies and social strategies.

This study was conducted in two primary schools situated in the rural areas in Southern Malaysia. A total of 70 simple random samplings among the Year 5 pupils were selected from the two different rural schools. The instrument used for data collection in this study is a survey adapted from the Strategy Inventory of Language Learning (SILL) which was developed by Rebecca L. Oxford. After getting permission from the respective school administrations, the researchers informed the respondents about the survey and the importance of their contribution to the success of the study. The researchers have clearly explained to the respondents that the survey is not an examination or a test, but just a study that needed carefully considered answers. Only one English lesson (30 minutes) was allocated for the respondents to answer the survey. A separate sitting was conducted for the absentees. The data were collected from the Strategy Inventory for Language Learning. The data were analysed descriptively. Comparison of means between the different language learning strategies was made to identify the most and least preferred strategies by the primary pupils in rural areas in Southern Malaysia in acquiring the English language skills.

\section{Findings and Discussions}

The findings of this research will be explored on the language learning strategies used by two rural primary school pupils. The strategies include memory strategies, cognitive strategies, compensation strategies, metacognitive strategies, affective strategies and social strategies. Discussion of strategies used is explained in the following section. 


\section{Table 1}

Memory Strategies

\begin{tabular}{|c|c|c|c|c|}
\hline No. & Items & $\begin{array}{l}\text { Yes } \\
(\%)\end{array}$ & $\begin{array}{l}\text { Maybe } \\
(\%)\end{array}$ & $\begin{array}{l}\text { No } \\
(\%)\end{array}$ \\
\hline 1 & $\begin{array}{l}\text { I think of relationships between what I already know } \\
\text { and new things I learn in English. }\end{array}$ & 52.86 & 35.71 & 11.43 \\
\hline 2 & $\begin{array}{l}\text { I use new English words in a sentence so I can } \\
\text { remember them. }\end{array}$ & 34.29 & 50.00 & 15.71 \\
\hline 3 & $\begin{array}{l}\text { I connect the sound of a new English word and a picture } \\
\text { of the word to help me remember the word. }\end{array}$ & 34.29 & 30.00 & 35.71 \\
\hline 4 & $\begin{array}{l}\text { I remember a new English word by making a mental } \\
\text { picture of a situation in which the word might be used. }\end{array}$ & 22.86 & 37.14 & 40.00 \\
\hline 5 & I use rhymes to remember new English words. & 30.00 & 32.86 & 37.14 \\
\hline 6 & I use flashcards to remember new English words. & 32.86 & 25.71 & 41.43 \\
\hline 7 & I physically act out new English words. & 17.14 & 34.29 & 48.57 \\
\hline 8 & I review English lessons often. & 27.14 & 54.29 & 18.57 \\
\hline 9 & $\begin{array}{l}\text { I remember new English words or phrases by } \\
\text { remembering their location on the page, on the board, } \\
\text { or on a street sign. }\end{array}$ & 35.71 & 35.71 & 28.57 \\
\hline
\end{tabular}

Based on Table 1, Item 1 is preferred by more than half of the pupils with $52.86 \%$. When the pupils think of the relationships between what they already know and new things they learn in English, they are using memory strategies to learn. The next item that normally used by the pupils in memory strategy is Item 9 which achieves $35.71 \%$. The pupils make use of the location on the page, on the board or the street sign to help them remember new English words or phrases. In contrast, the least preferred item in memory strategy falls on Item 7 (17.14\%) in which pupils seldom act out new English words in learning. 


\section{Table 2}

\section{Cognitive Strategies}

\begin{tabular}{llrrr} 
No. & \multicolumn{1}{c}{ Items } & $\begin{array}{c}\text { Yes } \\
(\%)\end{array}$ & $\begin{array}{c}\text { Maybe } \\
(\%)\end{array}$ & $\begin{array}{c}\text { No } \\
(\%)\end{array}$ \\
\hline 10 & I say or write new English words several times. & 51.43 & 51.01 & 12.86 \\
\hline 11 & I try to talk like native English speakers. & 42.86 & 24.49 & 75.57 \\
\hline 12 & I practice the sounds of English. & 51.01 & 59.19 & 32.66 \\
\hline 13 & I use English words I know in different ways. & 24.29 & 42.86 & 46.94 \\
\hline 14 & I start conversations in English. & 20.00 & 42.86 & 71.43 \\
\hline 15 & I watch English TV shows or movies spoken in English. & 27.14 & 53.06 & 51.01 \\
\hline 16 & I read for pleasure in English. & 32.66 & 59.19 & 51.01 \\
\hline 17 & I write notes, messages, letters, or reports in English. & 16.33 & 59.19 & 47.14 \\
\hline 18 & I first skim an English passage (read over the passage & 36.73 & 57.14 & 48.99 \\
& quickly) then go back and read carefully. & & & \\
\hline 19 & I look for words in my own language that are similar to & 48.99 & 46.94 & 46.94 \\
& new words in English. & & & \\
\hline 20 & I try to find patterns in English. & 32.66 & 45.71 & 31.43 \\
\hline 21 & I find the meaning of an English word by dividing it into & 32.66 & 59.19 & 51.01 \\
& parts that I understand. & & & \\
\hline 22 & I try not to translate word for word. & 36.73 & 46.94 & 59.19 \\
\hline 23 & I make summaries of information that I hear or read in & 14.29 & 45.71 & 57.14 \\
& English. & & \\
\hline
\end{tabular}

Table 2 shows the frequency of cognitive strategies used by the pupils. From the table, Items 10 recorded the highest frequency (51.43\%) among the pupils where they say or write new English words learned several times. Nearly half of the pupils prefer to learn this way. Another item which has the similar result is Item 12 with $51.01 \%$. During the process of learning, the pupils tend to practise the sounds of English to improve pronunciation. On the other hand, only $14.29 \%$ of the pupils choose to make summaries of information that they hear or read in English (Item 23).

Table 3

Compensation Strategies

\begin{tabular}{llccc}
\hline No. & \multicolumn{1}{c}{ Items } & $\begin{array}{c}\text { Yes } \\
(\%)\end{array}$ & $\begin{array}{c}\text { Maybe } \\
(\%)\end{array}$ & $\begin{array}{c}\text { No } \\
\text { (\%) }\end{array}$ \\
\hline 24 & $\begin{array}{l}\text { To understand unfamiliar English words, I make guesses. } \\
75.57\end{array}$ & $\begin{array}{l}28.57 \\
18.57\end{array}$ \\
\hline 25 & $\begin{array}{l}\text { When I can't think of a word during a conversation in } \\
\text { English, I use gestures. }\end{array}$ & 32.66 & 51.01 & 59.19 \\
\hline 26 & $\begin{array}{l}\text { I make up new words if I do not know the right ones in } \\
\text { English. }\end{array}$ & 36.73 & 53.06 & 53.06 \\
\hline 27 & I read English without looking up every new word. & 36.73 & 46.94 & 59.19 \\
\hline 28 & I try to guess what the other person will say next in English. & 53.06 & 27.14 & 51.01 \\
\hline 29 & $\begin{array}{l}\text { If I can't think of an English word, I use a word or phrase } \\
\text { that means the same thing. }\end{array}$ & 24.29 & 46.94 & 42.86 \\
\hline
\end{tabular}


From Table 3, Items 24 has the highest frequency. $75.57 \%$ of the pupils preferred to make guesses to understand unfamiliar English words. Meanwhile, pupils try to make guess of what the other person will say next during a conversation with $53.06 \%$ of the pupils agreed with this (Item 28). However, Item 29 is least favoured by the pupils where $24.29 \%$ of the pupils choose another word or phrase with the same meaning to replace the English word that they cannot think of.

Table 4

Metacognitive Strategies

\begin{tabular}{llccc}
\hline No. & \multicolumn{1}{c}{ Item } & $\begin{array}{c}\text { Yes } \\
(\%)\end{array}$ & $\begin{array}{c}\text { Maybe } \\
(\%)\end{array}$ & $\begin{array}{c}\text { No } \\
(\%)\end{array}$ \\
\hline 30 & I try to find as many ways as I can to use English. & 35.71 & 35.71 & 28.57 \\
\hline 31 & $\begin{array}{l}\text { I notice my English mistakes and use that information to help } \\
\text { me do better. }\end{array}$ & 30.00 & 48.57 & 35.71 \\
\hline 32 & I pay attention when someone is speaking English. & 50.00 & 28.57 & 21.43 \\
\hline 33 & I try to find out how to be a better learner of English. & 44.29 & 35.71 & 20.00 \\
\hline 34 & I plan my schedule so I will have enough time to study & 12.86 & 24.29 & 62.86 \\
\hline 35 & I look for people I can talk to in English. & 18.57 & 31.43 & 50.00 \\
\hline 36 & I look for opportunities to read as much as possible in English. & 28.57 & 32.86 & 38.57 \\
\hline 37 & I have clear goals for improving my English skills. & 25.71 & 44.29 & 30.00 \\
\hline 38 & I think about my progress in learning English. & 31.43 & 41.43 & 27.14 \\
\hline
\end{tabular}

Table 4 displays the data of the use of metacognitive strategies in pupils' second language learning. Referring to the table above, it is shown that $62.86 \%$ of the pupils do not plan their schedule to have enough time to study English and half of them do not look for people whom they can talk to in English. This data shows that pupils do not spend time and effort to think of learning English. In contrary, only half of the pupils tend to pay attention when someone is speaking English. However, $44.29 \%$ of them do try to figure out how to be a better English learner.

Table 5

Affective Strategies

\begin{tabular}{llccc}
\hline No. & \multicolumn{1}{c}{ Item } & $\begin{array}{c}\text { Yes } \\
(\%)\end{array}$ & $\begin{array}{c}\text { Maybe } \\
(\%)\end{array}$ & $\begin{array}{c}\text { No } \\
(\%)\end{array}$ \\
\hline 39 & I try to relax whenever I feel afraid of using English. & 38.57 & 42.86 & 18.57 \\
\hline 40 & $\begin{array}{l}\text { I encourage myself to speak English even when I am afraid of } \\
\text { making a mistake. }\end{array}$ & 42.86 & 34.29 & 22.86 \\
\hline 41 & I give myself a reward or treat when I do well in English. & 10.00 & 32.86 & 57.14 \\
\hline 42 & $\begin{array}{l}\text { I notice if I am tense or nervous when I am studying or using } \\
\text { English. }\end{array}$ & 31.43 & 38.57 & 30.00 \\
\hline 43 & I write down my feelings in a language learning dairy. & 12.86 & 24.29 & 62.86 \\
\hline 44 & $\begin{array}{l}\text { I talk to someone else about how I feel when I am learning } \\
\text { English. }\end{array}$ & 15.71 & 31.43 & 52.86 \\
\hline
\end{tabular}

According to the table above, $62.86 \%$ of the pupils do not have the habits of jotting down their feelings in a language learning diary. This could be meaning that they do not keep track on their learning progress. Besides that, more than half of the pupils do not give themselves a reward or treat when they perform well in English. Item 39 and Item 40 show 
that an average number of pupils try to relax whenever they are afraid of using English and also give encouragement to themselves to speak in English even though they are afraid of making mistakes.

Table 6

Social Strategies

\begin{tabular}{llrrr}
\hline No. & \multicolumn{1}{c}{ Item } & $\begin{array}{c}\text { Yes } \\
(\%)\end{array}$ & $\begin{array}{c}\text { Maybe } \\
(\%)\end{array}$ & $\begin{array}{c}\text { No } \\
\text { (\%) }\end{array}$ \\
\hline 45 & $\begin{array}{l}\text { If I do not understand something in English, I ask the other } \\
\text { person to slow down or say it again. }\end{array}$ & 41.43 & 35.71 & 22.86 \\
\hline 46 & I ask English speakers to correct me when I talk. & 21.43 & 37.14 & 41.43 \\
\hline 47 & I practice English with other pupils. & 22.86 & 45.71 & 45.71 \\
\hline 48 & I ask for help from English speakers. & 32.86 & 34.29 & 32.86 \\
\hline 49 & I ask questions in English. & 17.14 & 35.71 & 47.14 \\
\hline 50 & I try to learn about the culture of English speakers. & 21.43 & 34.29 & 44.29 \\
\hline
\end{tabular}

Table 6 portrays the frequency of social strategies used by the pupils. Item 45 has the highest frequency (41.43\%) where it shows that pupils are willing to seek for help such as requesting to slow down or to repeat if they do not understand something in English. However, there is only $17.14 \%$ of them will ask questions in English. On the other hand, nearly half of the pupils rarely ask English speakers to correct them when they talk, practise English with other pupils and try to learn about the culture of English speakers.

Table 7

Comparison of Means between different language learning strategies

\begin{tabular}{lccc}
\hline & Yes & Maybe & No \\
\hline Memory Strategies & 22.33 & 26.11 & 21.56 \\
\hline Cognitive Strategies & 18.43 & 26.29 & 25.29 \\
\hline $\begin{array}{l}\text { Compensation } \\
\text { Strategies }\end{array}$ & 22.00 & 22.67 & 25.33 \\
\hline $\begin{array}{l}\text { Metacognitive } \\
\text { Strategies }\end{array}$ & 21.56 & 25.11 & 24.44 \\
\hline Affective Strategies & 17.67 & 23.83 & 28.50 \\
\hline Social Strategies & 18.33 & 26.00 & 27.33 \\
\hline
\end{tabular}

Table 7 summarises the results on the language learning strategies used by the pupils. Memory strategies recorded the highest frequency which is $22.33 \%$. Chamot (2004) pointed out different cultural background students would have different strategies. According to Tyacke and Mendelsohn (1986) and Shi (2017), Asian students tend to use more memory strategies and compensation strategies rather than communicative strategies. Pupils preferred to relate their new knowledge to their previous knowledge when learning English. Moreover, compensation strategies have a similar result with memory strategies with only a difference of $0.33 \%$. Jabbari and Golkar (2014) established that "learners with a positive attitude employ cognitive, compensation, metacognitive and social strategies more frequently". In fact, the mean scores for 'No' are much higher 'Yes' which mean that these low achieving pupils rarely use language learning strategies in their learning. The data shown is in accordance with Javed and Ali's (2018) statement where they reported that high 
achievers were high strategy users where more usage of language learning strategies resulting in high academic achievement of students.

Findings in this study reveal that pupils in rural area use more memory strategies and rarely use other language learning strategies. As stated earlier, high achievers apply more strategies and also apply them accordingly to the goals; therefore, in order to improve the pupils' language learning process, teachers could assist them to learn about other language learning strategies and figure out the ones that suit them most by giving them proper direction and support. With the correct language learning strategies, the possibilities of pupils succeeding in language learning would be higher.

\section{Conclusion}

As a conclusion, this study shows that students apply various types of learning strategies in language learning. It is believed that the use of language learning strategies that suit the students would help them to have better learning experience. On top of that, teachers should also have better understanding in language learning strategies in order to help students learn more successfully and develop learning autonomy (Lee, 2010). Thus, it would be wise for teachers to be aware of their students' preference in order to design materials and activities that will cater to the students' needs and proficiency level. Discovering students' learning strategies and assisting them in the learning process are crucial for successful language learning.

\section{References}

Chamot, A. U. (2004). Issues in language learning strategy research and teaching. Electron. J. Foreign Lang. Teachnol. 1, 14-26.

Chamot, A. U. (1998). Teaching learning strategies to language students. Washington, DC: Center for Applied Linguistics.

Chamot, A. U., \& Kupper, L. (1989). Learning strategies in foreign language instruction. Foreign Language Annals, 22, 13-24.

Griffiths, C. (2004). Language learning strategies: Theory and research. AIS St Helens, Centre for Research in International Education.

Hashim, H. U., Yunus, M. M., \& Hashim, H. (2018). Language learning strategies used by adult learners of teaching English as a second language (TESL). TESOL International Journal, 13(4), 39-48.

Jabbari, M. J., and Golkar, N. (2014). The relationship between EFL learners' language learning attitudes and language learning strategies. Int. J. Linguist. 6, 161-167. doi: 10.5296/ijl.v6i3.5837

Javed, M., \& Ali, A. (2018). Analysing the use of language learning strategies among high and low achievers. Journal of Research and Reflections in Education, 12(1), 25-44.

Lee, C. K. (2010). An overview of language learning strategies. Annual Review of Education, Communication \& Language Sciences, 7.

Lessard-Clouston, M. (1997). Language learning strategies: An overview for L2 teachers. The Internet TESL Journal, 3(12). http://iteslj.org/Articles/LessardClouston-Strategy.html

Macaro, E. (2006). Strategies for language learning and for language use: Revising the theoretical framework. The Modern Language Journal, 90(3), 320-337.

O'Malley, J. M., \& Chamot, A. U. (1990). Learning strategies in second language acquisition. The Cambridge Applied Linguistic Series. Cambridge: C.U.P 
Oxford, R. L. (2003). Language learning styles and strategies: An overview. Oxford, GALA, 125.

Oxford, R. L. (1986). Second language learning strategies: Current research and implications for practice. Center for Language Education and Research. Los Angeles: CA.

Saad, N. S. M., Sidek, H. H. M., Baharun, H., Idrus, M. M., \& Yunus, M. M. (2016). A conceptual framework to explore the English language learning experiences of international students in Malaysia. International E-Journal of Advances in Education, 2(6), 453-464.

Saad, N. S. M., Yunus, M. M., \& Embi, M. A. (2012). Research on international students in traditional host countries and Malaysia: Some potential areas in Malaysia. Paper presented at the 6th International Conference on University Teaching and Learning (InCULT) 2012, Concorde Hotel, Shah Alam, 20- 21 November 2012.

Scarcella, R., \& Oxford, R. (1992). The tapestry of language learning: The individual in the communicative classroom. Boston: Heinle \& Heinle.

Shi, H. (2017). Learning strategies and classification in education. Institute for Learning Styles Journal, 1(1), 24-36.

Tyacke, M., \& Mendelsohn, D. (1986). Student needs: Cognitive as well as communicative. TESL Canada Journal, 1, 171-183. 